\title{
Digital interventions with families - a case study
}

\author{
Lo digital en la intervención con familias: un caso práctico
}

Els mitjans digitals en la intervenció amb famílies: un cas pràctic

\author{
Patricia Vegard $^{1 \oplus}$, Helena Belchior-Rocha ${ }^{2, * \circledast}$, Inês Casquilho-Martins ${ }^{1 \oplus}$ \\ 1 | CLISSIS - Lusíada Research Centre for Social Work and Social Intervention, Instituto Universitário de \\ Lisboa, Lisboa, Portugal \\ 2 | Department of Political Science and Public Policies, University Institute of Lisbon (CIES), Lisbon, Portugal \\ ${ }^{*}$ Corresponding author: helena_rocha@iscte-iul.pt (Helena Belchior-Rocha)
}

Received: 07/30/2021 | Accepted: 11/11/2021 | Published: 01/15/2022

\begin{abstract}
This article discusses the responses developed in Portugal during the state of emergency by a family empowerment and intervention team and how this team actively integrated contingency plans and challenges through information and communication technology (ICT). We also explain what was learned during this period and what could have been done better. The family empowerment intervention teams of this organization are specialized multidisciplinary teams that act from a transdisciplinary perspective to teach parenting skills to families to ensure that the rights of their children and adolescents are guaranteed. These teams' interventions normally take place in the home environment. However, the state of emergency meant that this procedure had to be adapted by incorporating digital practices, while home visits and consultations were carried out only in emergencies and other duly justified situations. The result of this experience was extremely positive in terms of the relationships established with the families and couples, the skills developed, and the resilience shown by all.
\end{abstract}

KEYWORDS: Social Work; parenting skills; digital practices

Citation: Vegard, P., Belchior-Rocha, H. y Casquilho-Martins, I. (2022). Digital interventions with families - a case study. Research in Education and Learning Innovation Archives, 28,37-49. 10.7203/realia.28.21413

Copyright: The Authors. Open Access: This article is distributed under the terms of the Creative Commons Attribution-NoDerivatives 4.0 International licence (CC BY-ND 4.0)

Funding: None informed
RESUMEN: Este artículo comparte las respuestas desarrolladas durante el periodo de emergencia en Portugal por un equipo de empoderamiento e intervención familiar y cómo integraron activamente los planes de contingencia y los retos planteados a través de las tecnologías de la información y la comunicación (TIC), lo que se aprendió y lo que se puede hacer mejor. Los equipos de intervención de formación familiar de esta organización son equipos multidisciplinares especializados que trabajan en una perspectiva transdisciplinar con el objeto de formar a las familias en la promoción de las habilidades parentales, de forma que los niños y jóvenes tengan garantizados sus derechos. La intervención de estos equipos se realiza principalmente a domicilio, pero con la entrada del estado de emergencia, sufrió algunas adaptaciones, con recursos a prácticas digitales, y las visitas y consultas a domicilio sólo se realizaron en casos urgentes y debidamente justificados. El balance de esta experiencia fue muy positivo tanto por la relación con las familias y los(as) compañeros(as), como por las habilidades que se trabajaron y la resiliencia mostrada por todos.

PALABRAS CLAVE: Trabajo Social; habilidades parentales; prácticas digitales

RESUM: Aquest article presenta les respostes que donaren els membres d'un equip de treball sobre formació i intervenció familiar en el període d'estat d'emergència a Portugal, la forma com van integrar activament els plans de contingència i els reptes plantejats a través de les tecnologies de la informació i la comunicació (TIC), el que aprengueren i el que es pogué haver fet millor. Els 
equips d'intervenció de formació familiar d'aquesta organització són multidisciplinaris i especialitzats i treballen en una perspectiva transdisciplinària amb l'objectiu de formar els membres de les famílies en matèria d'habilitats parentals, de manera que els xiquets i els joves tinguen garantits els seus drets. Aquests equips intervenen principalment en la llar, però amb l'estat d'emergència es van fer algunes adaptacions amb recursos digitals, visites a domicili i assistència només en casos urgents degudament justificats. El balanç d'aquesta experiència va ser molt positiu tant pel que fa a la relació amb les famílies i les parelles, com pel que fa a les habilitats que es van estudiar i la resistència que demostrà tothom.

PARAULES CLAU: Servei social; habilitats parentals; pràctiques digitals

\section{Practitioner Notes}

\section{What is already known about this topic}

- This research is useful teaching methodology to integrate information and communication technologies in theory and practice in teacher education.

- Literature about intervention through new information and communication technologies referring it presents itself as an opportunity for adaptation and innovation in Social Work

- Intervention with technologies allow for the optimization of online resources available in a global and digital society

\section{What this paper adds}

- Introduces and explores the use of technologies in practice and how it's possible to create alternatives and strategies in the field

- Offers good practice example for university educators to support in their teaching education and for professionals to follow the example in their practice

- Emphasis the possibility of using already existing simple digital resources to apply in the daily practice

\section{Implications for practice and/or policy}

- Emphasis should be put on alternatives connecting theory and practice with technologies going from the literature review reflected in the social workers training, combining flexibility and adaptation to the new guidelines that are emerging and which is pertinent to share and debate, demonstrating how technologies can complement our intervention at various levels

\section{INTRODUCTION AND REVIEW OF THE LITERATURE}

The demographic, cultural, political, economic and social changes that have occurred in recent decades are reflected in families. It is not our intention to make an exhaustive chronology of these events, but only to substantiate our perception, we can refer the Revolution of 25th April 1974 as the transition from the dictatorial regime to a democratic state (Pimentel, 1999) emphasizing that, until then and although the Salazar ideology gave special emphasis to family and motherhood. The state protection provided to families and mothers was little more than non-existent, considering that the role, in relation to assistance, was merely supplementary and relied on the charitable character of the Portuguese (Casquilho-Martins, 2018; Pimentel, 1999). The second major milestone was Portugal's entry into the European Economic Community, now the European Union (EU), which was followed by the globalization of markets, the financial crisis of 2008 and the recent pandemic situation that not only affects the public health level but also the economic, social, and political level. Today, family structure and configurations vary among the most classic, that reproduce the traditional model (mother, father, children), to the most complex levels in defining the family group configuration (Correia, 2020). The composition of the family today is far beyond the biological and legal factors, making the aspects of subjectivity important in the family configuration and demanding greater legitimacy and acceptance by society (Wagner, 
Spiker, Linn, \& Hernandez, 2003). Therefore, research focused on family intervention has also changed.

\subsection{Families, children and social protection}

In a study carried out by Wall (2005) the author says that the family structure in Portugal has changed a lot since we join the European Community. Portuguese get married less, later in life, and postpone parenthood like the other community partners. Divorces increased, more out-of-wedlock births and, above all, fewer children, which contributes to the shrinking of family units. Children stay at home late, a characteristic of Southern Europe. And although the number of single people has increased, we are far from the average. Households are smaller, and the number of couples living with a father, a mother or an uncle has decreased, we went from the country with the highest birth rate to the lowest.

Sousa, Hespanha, Rodrigues, and Grilo (2007) consider that "we must reframe the definition of socially vulnerable families" in order to look at skills and potentials and not only at problems. For Ausloos (2003) "to speak of a competent family is, therefore, a way of giving the family its competence, before taking into account its shortcomings". The idea of continuity in family problems is evoked (permanent crisis, problematic, chronically dysfunctional and multi-stressed) from which emerges the idea of permanence or absence of interruption in adverse events, which generates negative expectations that, in our perception, extends not only to the families themselves, but also to the social workers who accompany them. Collins, Madsen, and Susman-Stillman (2002), warn that there is a tendency for these designations to become "self-fulfilling prophecies" and that professionals often focus on the lack of change in these families and on the perpetuation of patterns over generations. But as we know, this means that when people believe or expect something to happen, they end acting like if nothing is going to change and of course their prediction actually comes true. That is precisely what needs to change, starting with the social workers. Unless if we use it positively, and in that case, we would probably turn around the previous focus and the pattern would change. In fact, what we mean is that social workers cannot remain in this mind set, since our commitment is with is linked with the purpose of contributing to the creation of mechanisms that enable changes for those we work with.

The form of family functioning, experienced by its elements, presents itself nowadays with different formats from other times, as already mentioned in this work (family, structure and functioning). Therefore, the variety of configurations of family relationships have an impact on the family, having consequences at the psychological, emotional and social level of the child (Rodrigues, 2012). The forms of relationship between family members, give the type of family dynamics, ie, are the ways in which the elements create and maintain links with each other. So how they present themselves in front of problem situations, their customs, the family rules developed, the definition, importance and respect of the family hierarchy.

Family members may belong to different subsystems, and in each subsystem, they experience different forms of power, such as the possibility of acquiring different personal skills.

Bayle and Martinet (2008) refer that today's family shows more interest in emotional and affective issues due to changes at various levels, such as sociocultural, technological, environmental, political and religious. The family is in permanent mutation, it does not present solidity.

For the child, the family presents itself as a group of people who love them and give them security through the representation of their roles, and for whom parents should present themselves as caring individuals, for all the needs and for a harmonious development of their children. 
Article $68^{\circ}$ of the Constitution of the Portuguese Republic (CRP) on paternity and maternity establishes that:

Fathers and mothers have the right to protection from society and the State in the performance of their irreplaceable action in relation to their children, namely as regards their education, with a guarantee of professional achievement and participation in the civic life of the country. Not only is the education of children foreseen as a right of parents, but the double aspect of a right/power/duty is also highlighted, as foreseen in Art. 36: Parents have the right and duty to educate and maintain their children, in which the spouses enjoy equal rights and duties; children may not be separated from their parents, except when the latter fail to fulfill their fundamental duties to them and always by judicial decision.

Not only is the education of children foreseen as a right of parents, but the double aspect of a right/power/duty is also highlighted, as foreseen in Art. 36:

Parents have the right and duty to educate and maintain their children, in which the spouses enjoy equal rights and duties; children may not be separated from their parents, except when the latter fail to fulfill their fundamental duties to them and always by judicial decision.

In the same sense, Article 4 of the Law for the Protection of Children and Young People in Danger (LPCJP) is embodied in these principles, clarifying and reinforcing the importance of parental responsibility, as well as the need for an action that considers the involvement of the family in problem solving.

It's important to check the level of interaction between family members, analyzing the degree of indifference and passivity when children ask their parents for attention. The moments of play between parents/children.

The services and activities are aimed at preventing social exclusion and improving the quality of life of individuals and families in situations of fragility and social vulnerability. This institution is a resource center that, by the nature of its intervention, characterized by close relationships, provides a support context that facilitates intervention.

The services and activities provided aim to meet the basic needs detected and promote, in parallel, the development of skills in individuals, with a view to their autonomy, such as: Food support, Laundry, Social and Cultural Animation, School Support, Skills Development Space, Employment and Housing Space and Information/Awareness Raising Actions.

Conditions for access are: Being a resident in the city of Lisbon; Being 65 years of age or younger, unless otherwise advised by a technical opinion. The request for access is made by the institution's services or by other entities in the city of Lisbon through a referral form, which will be made available whenever requested.

\subsection{Social intervention and digital practices during pandemic}

The uncertainty and instability generated by the current pandemic aggravated the scenario of social needs and problems to which children and young people were already exposed, increasing their vulnerability to poverty and social exclusion (CasquilhoMartins, 2018; Picornell-Lucas, 2020b). With the limitation in face-to-face contacts during the pandemic, social intervention needed to reconfigure its forms of action and proximity, minimizing its negative effects on the relationship with families (Cardoso, Vilar, \& Casquilho-Martins, 2020). 
Social intervention during the pandemic highlighted the need to find strategies to guarantee the well-being and rights of children and young people (Baginsky \& Manthorpe, 2021; Bennett et al., 2021; Danese \& Smith, 2020; Dominelli, 2021; Pink, Ferguson, \& Kelly, 2020). In this period, there were significant changes in the forms of contact of social workers, namely through the substitution of face-to-face contacts by virtual contacts due to the closure of social services (Cook \& Zschomler, 2020; Singer \& Brodzinsky, 2020).

The intervention carried out by family support teams framed in Family Support and Parental Counseling Center (CAFAP) develops a close and systematic intervention with families, aiming at the protection of the most vulnerable groups, namely children and young people, to whom it is necessary to respond with specialized family support mechanisms (Decree $n^{\circ}$ 139/2013, of April, 2nd).

Thus, through interdisciplinary teams, this intervention aims to promote the exercise of positive parenting, through empowerment and autonomy processes that contribute to family well-being and the realization of children's rights. This leads to intervention models that emphasize family assessment and the psychosocial risk situation of families, leading to action plans structured according to the particular situation of each family. On the other hand, these actions also aim for a systemic, intensive and dynamic approach of an integrated and regular nature, allowing for knowledge and a global vision of the family structure and dynamics (CNPDPCJ, 2021).

Before the emergence state caused by COVID-19, the work of the CAFAP teams had a dimension of close contact with families and partners, but using more conventional models, i.e., the use of digital media was essentially focused on intra- and interorganizational communication. The intervention contexts were mostly face-to-face with families and children in their natural living environment, i.e., with the caregivers (Decree $\mathrm{n}^{\circ}$ 139/2013, of April, 2nd). If the child was institutionalized, the intervention took place in the process of return to the family. The family intervention is an intrusive type, in which many of the caregivers have low self-esteem regarding parenting, and the close and systematic work is essential for their autonomy. Many of the families that are part of the team's actions had already been accompanied for several generations through other social services. The transdisciplinary work is complemented by a focus on structural issues such as the socio-economic conditions of families, personal and social skills, employability, training and schooling, combined with the specificity of the intervention in promoting parental empowerment. There are defined protocols from the moment the families are received, which start from a diagnostic evaluation to understand the family context and design an intervention plan appropriate to each situation. Among the most commonly diagnosed intervention problems is neglect, mainly at the level of health care and basic care, especially when the children are young. Physical abuse as a form of punishment are also cases that force the team to work with caregivers to develop educational strategies that do not involve physical aggression. In the most serious cases, the cases are reported to other instances, namely to the security forces for judicial referral.

It should be noted that all intervention with the families must be consented by them. The experience of these teams indicates that families voluntarily accept the intervention of social workers because they prefer to avoid judicial involvement and express concern about the situation with their children. It is also important that families are informed of the whole process and of the actions in which they will be participatory agents, having the right to know the reason for the intervention and the opportunity to agree or disagree with the process, evolving in a collaborative process with the team in an active way. Home visits are therefore one of the privileged means for the family's physical, social and personal space to be the space of intervention, following the family routines and dynamics. 
The systemic and ecological model of intervention allows for a transversal intervention at the micro, meso, and macro levels, although the results are manifested on an individual and family scale rather than a structural one. However, the work of the social worker should always seek to bring about social change in a structural domain (Belchior-Rocha, 2018) that allows for the prevention and mitigation of the prevalence of situations of risk and danger.

In this case, if more families can feel that can ask for help, more families can be achieved and supported. Mishna, Bogo, Root, and Fantus (2014) has stated that "the necessity of these expansions is clear when considering the far-reaching impact of information and communication technology, not only on children and youth, but on individuals of all ages (Mishna et al., 2014), believing that are many approaches, possibilities and strategies that can continue to be developed at each ecological level: individual, family and community.

According to Barros (2020), the intervention in the natural environment of life contributed to the development of parental skills and competencies necessary for the child's growth in a safe family environment. However, it is verified that the changes in daily life and the new measures to prevent contagion during the health crisis presented themselves as "a challenge to their lives, their routines, their access to basic services and, ultimately, to the guarantee of their rights" (Picornell-Lucas, 2020a). Thus, not only did the work of the intervention teams encounter new obstacles, but the children's relationships, participation and opportunities became more limited and compromised. Noteworthy are the difficulties in contacts with users, increased internal tensions, feelings of uncertainty and insecurity, difficulties in dealing with a new and unknown situation, the difficulties inherent in telecommuting, also affecting the reconciliation between work and family life (Cardoso et al., 2020).

Therefore, there is a concern on the part of citizens and social workers to promote the guarantee of social welfare systems, ensure responses and social services to their users and invest in best practices (López-Peláez, Marcuello-Servós, De-Mesa, \& Almaguer-Kalixto, 2020), particularly through intervention through digital means. The use of networks and digital work contributes to the reconfiguration of places and ways of working due to the greater need to reduce face-to-face contacts, without breaking direct contact with citizens, using and creating communication channels and flexible digital connections between organizations, professionals and the citizens themselves (Cardoso et al., 2020).

The use of technology also changes social work. For example, we can provide clients or users with remote (not in person) services. Of particular interest is social work's potential to reach traditionally isolated, dispersed areas, in rural, difficult-to-access locations; and even social work's capacity to access networks of resources, information, contact with public and private entities, and so on (Barrera-Algarín, Sarasola-SánchezSerrano, and Sarasola-Fernández, 2021, p.2).

Intervention through new information and communication technologies presents itself as an opportunity for adaptation and innovation in Social Work intervention, allowing for the optimization of online resources available in a global and digital society (López-Peláez \& Marcuello-Servós, 2018). However, the adequacy of digital practices implies knowledge of the tools to be used, but also compliance with ethical standards in the field of risks that may emerge in the use of technology in intervention (Reamer, 2018).

\section{MATERIALS AND METHODS}

The first phase of the pandemic caught us all by surprise, but we quickly reacted and came up with alternative strategies to intervene with these families. In this sense, it was necessary to rethink the intervention in order to maintain a close follow-up, even 
without physical presence. Maintaining the promotion of a positive parenting and ensuring rights, mainly at the level of access to education and access to health. And above all, ensuring that home is a safe place for the children and young people we accompany.

The contributions of this case analysis are intended to consolidate the theoretical, methodological and ethical knowledge of Social Work with new ways of intervening through an action-research methodology as a form of reflexive and collective questioning, seeking the improvement of social practices, as well as the understanding of these practices and the situations in which they are developed (Kemmis \& Mctaggart, 1988). Thus, it is a collaborative research, because besides the role of the researcher, it is co-constructed and analyzed with the participants involved. We are thus facing a methodology that is characterized by the production of knowledge through the action of social groups and participating subjects (Mayer \& Ouellet, 1991). The role of the researcher is also assumed as an intervener to promote awareness of the problem and help individuals and groups to solve it, obtaining results that allow him to plan and implement actions that can be critically reflected (Carvalho-Guerra, 2002).

From a total of 40 accompanied families, 31 families participated in this experience, the rest either did not have digital resources or did not want to. As for the characterization of families, mostly had low and middle income, with diversity configurations: Single-parent families, reconstructed families, large families and extended families. Among the main risks signaled in these families we could found, mistreatment and neglect, domestic violence, among other risks that could compromise the development, well-being and safety of children and youth.

The period in which it took place, started in the end of March 2020 (when the first confinement took place), until the end of September 2020. The families were initially contacted by telephone, and as was mentioned 31 from the 40 families adhered to this new modality of intervention. In the initial contacts, the objectives of the sessions were explained, maintaining the guarantee of confidentiality and voluntariness in the intervention. During the period in which a digital intervention methodology was applied, there were no dropouts.

Among the families who participated in digital practices, we used as preferred contact tools, Zoom, Skype and WhatsApp and 7 of them also integrated the use of padlet as a collaborative tool. The forms of digital contact ranged from daily to once-aweek contacts. Another factor that conditioned the frequency of contacts was the hazard categorization, that is, families at higher hazard contacts were daily, families at medium hazard contacts were 3 times a week. Families with low danger were weekly. Participation with the padlet was weekly, with online contacts being adjusted to families' participation availability. Zoom sessions took between 45 mins and 90 mins, depending on the goal of the session. Family reflection activities took less time than sessions that included games and dynamics for wider participation.

Through the permanent involvement of families and the evaluation of the previously established intervention plans, namely through records and social information, it was verified that the cases of danger signaling did not evolve and that in some families they decreased, allowing the evaluation of the follow-up process during this period. At the end of each weekly session, evaluation exercises were also applied with the participation of families, in which their satisfaction with the project activities was evident, allowing a continuous and final evaluation of the activities carried out.

Through the diagnoses and the work previously done, we identified the level of risk and danger of each family and based on this identification we determined the minimum number of weekly contacts.

In the first phase we assured the basic needs of the families, we worked with the children so that they could ask for help in a dangerous situation. An example of one of the strategies used was to tell a story about the professions, where the children 
learned who to turn to if they felt in danger (e.g. 112 line), as well as to memorize their home address. We also established safety words, so that during contacts they could ask us for help safely.

We have strengthened the articulation with services and partners, which allowed us to respond to families' needs without them having to move between services, but also a more agile information sharing. Thus, we have created new networking mechanisms, with more computerized procedures centralized in our team, instead of people having to go to the various services.

Every time we became aware of the possibility of a dangerous situation, we conducted joint home visits with other protection services, or face-to-face meetings in order to better diagnose the situation.

The meetings and case discussions were not suspended, but moved to an online format, through the Team's platform it was still possible to build reports and social information, as well as compile records, update diagnoses and create new intervention plans.

During this period, we began to use technology as our greatest ally, both through the use of communication tools such as Skype and WhatsApp, the meetings and activities became through video calls and instant communication either through WhatsApp or email increased greatly in frequency and volume, this allowed a real time approach to families, which had been broken by the need for physical distance.

We also used collaborative platforms such as Padlet, a collaborative tool that allows interaction between the staff and the family, both in sharing activities and strategies. The fact that the layout is simple and has the format of a website, allows it to be accessed both by families with less digital literacy and by families with greater technological knowledge. Through Padlet families can perform the proposed activities, but also propose other activities or share the results.

Later on, Padlet was adapted to promote the autonomy of families in accessing services, we started to create and publish short videos on how to access direct social security, do online registration, schedule appointments in public services, etc.

Through the use of these tools, it was possible to carry out joint activities with the family in order to work on previously identified stressful and/or dangerous factors, and identify new warning signs of both risk and danger.

To do this we had to work on reading body language, tone of voice and positioning of the family through the reading of micro expressions, and video calls with the various elements either together or individually.

We continued to work on family dynamics and relationships, as well as personal empowerment and economic management. An example of a strategy in this area was making shopping lists and budgets using hypermarket websites, so that the family could know approximately how much they would spend and what they would need to buy, taking advantage of these moments to work on other necessary dimensions such as routines and food. Our objective was to work on the autonomy and digital literacy of our families, so that they can autonomously use the existing services digitally.

Considering ethical issues, we understand that its difficult, like Pascoe (2021) refers, to guarantee confidentiality when communicating online, but it is important that from now on, practical steps can be taken to improve cyber security (Pascoe, 2021).

Also, we are aware and defend that an informed consent is required before engaging in this kind of services and that should be applicable in any circunstances (Pascoe, 2021). Informed consent should include a previous discussion about what participants can expect and what is appropriate to discuss or not when recurring to technologies (Pascoe, 2021). For Reamer (2017) online services can become an ethical dilemma, concerning the identity of the service user and other issues, since not always is accurately represented, may be difficult to confirm, and the parental consent for minors must be safeguarded. Nevertheless, the issues of confidentiality and data protection 
can never be in question, so, even as tools to be used, online practices have to have guarantees for the users, and this is and will one biggest challenge.

From here arises a reflection that allows contextualizing the implications of a reflective practice, given that action research aims to contribute to the development of practices, change of practices or contributions to new practices (Coutinho et al., 2009) in social intervention with families and children at risk.

\section{RESULTS}

In this section we present the results that were obtained through this experience of digital intervention with families, children, and young people.

The current pandemic context led to an analysis of models for sharing practices in digital intervention with families and children at risk during the health crisis. Despite the constraints caused, this situation brought a closer relationship between the team and all the family members, because we were with the families on a daily basis to help them overcome difficulties as they arose.

The participation of the families in this project allowed the teams to maintain an approach to social accompaniment, supporting them in facing the challenges of the pandemic context. Being a new modality of contact, the adaptation to digital tools presented itself as an innovation in the close relationship between professionals, families, and children. We found that participants were receptive to the use of digital platforms. The discovery of new ways of interacting also contributed to maintaining the initial curiosity and motivation throughout the activities, since none of the families abandoned the project.

It has enhanced networking and more agile and concerted mechanisms by all areas in order to ensure the protection of children and young people, but also the well-being and stability of the family.

The current balance was very positive both in terms of the relationship with families and partners, and in terms of the skills that have been worked on and the resilience shown by all.

Family relationships were perceived as more robust, considering that through the evaluation arising from the intervention, a decrease in risk and danger situations, which had previously been categorized, was verified. We cannot state that these situations were totally verified, because the non-face-to-face contact does not allow us to accurately assess the family context. However, according to the risk categorization established, we noticed that the families and children presented a greater emotional stability in the contacts with the teams and that no situations of aggravation or increased risk were reported.

The families also showed skills that we didn't know and an acceptance of the integration of technology in the intervention, with this receptivity it was possible to move quickly from a crisis response intervention to a planned and intentional intervention still during the crisis.

As professionals, it is fundamental that social workers, regardless of the contexts and their limitations, have the ability to believe in the parents' potential for change and in a transformation that leads to the well-being of the children. In this sense, innovation and adaptation in a pandemic context became fundamental to boost life projects that ran more risks and a greater exposure to social exclusion and the worsening of problems and needs diagnosed.

These results had an important significance in the pandemic context and lockdowns, and it was expected that new situations of danger could be manifested in the accompanied families.

The introduction of tools and programs based on digital technologies, thus allowed to maintain collaborative relationships and mitigate the limitations to the work of 
direct intervention with families, promoting new ways to enhance social and human relationships. One of the great challenges is to be able to establish and maintain an emphatic and trusting relationship, being sensitive to people's problems and managing joint solutions that allow us to take advantage of intervention opportunities, even in a crisis context.

\section{DISCUSSION AND CONCLUSIONS}

The effects of the health crisis in COVID-19 call into question the fundamental rights of all citizens, particularly children, who are more exposed to risks such as violence, limited access to the education system and greater exposure to poverty (PicornellLucas, 2020b). In a period marked by the imposition of physical and social distance, the context of intervention is marked by a greater integration of new digital technologies of information and communication, in the increase and use of telephone helplines, in the implementation of specific activities to support families and monitoring of children and young people, even at a distance, and other innovative projects (Cardoso et al., 2020). These data are important to highlight the centrality and relevance of the functioning, maintenance and promotion of networks and social relationships in the areas of social intervention, due to the particularity of the context of the responses and social services themselves during the pandemic.

For López-Peláez, Pérez-García, and Massó (2017) intervention through online tools articulated with outreach work can integrate a specialty field of Social Work, responding to social and technological transformations that require responses that are more adapted to current societal challenges.

We learned that both at the intervention level and at the level of a greater commitment to digital literacy for all, so that we can increasingly integrate digital practices to face-to-face intervention.

One of the lessons is the importance of starting to integrate technologies as an ally and complement to the intervention, we will start to introduce this in the parents' group that was suspended but will resume with face-to-face sessions and online sessions and with the creation of an exclusive Padlet for it, which will aim to enhance co-creation and co-responsibility that is at the genesis of the group's creation and the group itself as a support network.

Several recent studies referenced by Barrera-Algarín et al. (2021); Reamer (2017), indicate that ICT's are one of new instruments for Social Work, we highlight Baker, Warburton, Hodgkin, and Pascal (2014), who believe in the application of new technologies in social work through Participatory Action Research (PAR).

Thinking about the future and what we can gain from this experience, we know that the pandemic of COVID-19 leaves us with impacts that are difficult to count, challenges for which there was no predictability, but it is a reality that we will have to live with, besides the possibility of other similar or more serious situations.

As a practical experience some limitation should be referred. This study refers to an investigation of one's own practice, in an emergency context, and intended to provide information on strategies that can be implemented in similar situations; it does not aim at any kind of generalization. Social workers have historically been confronted with challenges that sometimes leave them constrained, which is why it is important to share experiences in the field, lived in real time and not subject to later narratives already filtered by discourses of right or wrong.

Authors like Saitadze and Dvalishvili (2021) have concerns about the readiness for practice of the new graduates in Social Work, that have been raised across a lot of countries. The challenges that students face when they leave the academic life and start the professional practice are many times associated with the lack of proximity between what they learn and the reality they face. 
We have no doubt that social workers will be key agents for society to rebuild. Family and social relationships will have to be dealt with, and the situation of stability and accompaniment to families at various levels will have to be returned, and the implementation of new social policies in this sense is urgent. But one cannot wait, we have to adapt and anticipate scenarios, which requires:

Resilience and perseverance ensuring working conditions so that teams continue to treat and accompany families, having direct access to the indispensable resources to resolve situations of risk resulting from forced and voluntary isolation; Motivation and focus, on family and social well-being, enhancing an environment of understanding within the teams; Strengthen network articulation.

We consider these to be some of the points for which social workers should be trained, combining flexibility and adaptation to the new guidelines that are emerging and which we consider pertinent to share, reflect on and debate, demonstrating how technologies can complement our intervention at various levels.

\section{REFERENCES}

Ausloos, G. (2003). A Competência das famílias - tempo, caos, processo. Lisboa: Climepsi Editores.

Baginsky, M., \& Manthorpe, J. (2021). The impact of COVID-19 on Children's Social Care in England. Child Abuse and Neglect, 116(2). https://doi.org/10.1016/j.chiabu.2020.104739

Baker, S., Warburton, J., Hodgkin, S., \& Pascal, J. (2014). Reimagining the Relationship between Social Work and Information Communication Technology in the Network Society. Australian Social Work, 67(4), 467-478. https://doi.org/10.1080/0312407X.2014 928336

Barrera-Algarín, E., Sarasola-Sánchez-Serrano, J. L., \& Sarasola-Fernández, A. (2021). Social work in the face of emerging technologies: A technological acceptance study in 13 countries. International Social Work. https://doi.org/10.1177/00208728211041672

Barros, J. P. (2020). Uma terceira via? - a aplicação simultânea de medida em meio natural de vida e em regime de colocação in Centro de Estudos Judiciários. In E. Taborda-Lopes \& A. Caçapo (Eds.), A Criança em Perigo e a Proteção dos Seus Direitos; Multiplicidade na Intervenção (pp. 181-206). Lisboa: CEJ. Retrieved from http://www.cej.mj.pt/cej/ recursos/ebooks/familia/eb_CriancaEmPerigo2020.pdf

Bayle, F., \& Martinet, S. (2008). Perturbações da Parentalidade. Lisboa: Climepsi.

Belchior-Rocha, H. (2018). Social Work Practices and the Ecological Sustainability of Socially Vulnerable Communities. Sustainability, 10(5), 1312-1312. https://doi.org/10.3390/ su10051312

Bennett, E. R., Snyder, S., Cusano, J., Mcmahon, S., Zijdel, M., Camerer, K., \& Howley, C. (2021). Supporting survivors of campus dating and sexual violence during COVID-19: A social work perspective. Social Work in Health Care, 60(1), 106-116. https://doi.org/ 10.1080/00981389.2021.1885566

Cardoso, J., Vilar, D., \& Casquilho-Martins, I. (2020). Relatório do estudo - Desafios ao Serviço Social no contexto da COVID-19. CLISSIS. CLISSIS. Online

Carvalho-Guerra, I. (2002). Fundamentos e processos de uma sociologia de ação: o planeamento em Ciências Sociais. Cascais: Principia.

Casquilho-Martins, I. (2018). Modelos de proteção social em sociedades com programas de austeridade (Doctoral dissertation, Instituto Universitário de Lisboa, Lisboa). Retrieved from http://hdl.handle.net/10071/18785

CNPDPCJ. (2021). Relatório Anual de Avaliação da Atividade das CPCf 2020. Lisboa: Comissão-Nacional-de-Promoção-dos-Direitos-e-Proteção-das-Crianças-e-Jovens (CNPDPCJ).

Collins, W. A., Madsen, S. D., \& Susman-Stillman, A. (2002). Parenting during middle childhood. In M. H. Bornstein (Ed.), Handbook of parenting: Children and parenting 
(pp. 73-101). Lawrence Erlbaum Associates Publishers.

Cook, L. L., \& Zschomler, D. (2020). Virtual Home Visits during the COVID-19 Pandemic: Social Workers' Perspectives. Social Work in Action, 32(5), 401-408. https://doi.org/ 10.1080/09503153.2020.1836142

Correia, R. F. (2020). Policy Brief 2020 - Efeitos da Pandemia nas Famílias Portuguesas: Principais Impactos, Legislação e Medidas Governamentais entre Março e Agosto de 2020. Lisboa: ICS - Observatório das Famílias e das Políticas de Família. Retrieved from https://www.ics.ulisboa.pt/flipping/ofap2020_2/

Coutinho, C. P., Sousa, A., Dias, A., Bessa, F., Ferreira, M. J., \& Vieira, S. (2009). InvestigaçãoAcção: Metodologia preferencial nas práticaseducativas. Revista Psicologia, Educação e Cultura, XIII(2), 355-379. Retrieved from http://hdl.handle.net/1822/10148

Danese, A., \& Smith, P. (2020). Debate: Recognising and responding to the mental health needs of young people in the era of COVID-19. Child and adolescent mental health, 25(3), 169-170. https://dx.doi.org/10.1111/camh.12414

Dominelli, L. (2021). A green social work perspective on social work during the time of COVID-19. International fournal of Social Welfare, 30(1), 7-16. https://doi.org/10.1111/ ijsw.12469

Kemmis, S., \& Mctaggart, R. (1988). The action research planner. Victoria: Deakin University Press.

López-Peláez, A., \& Marcuello-Servós, C. (2018). e-Social work and digital society: reconceptualizing approaches, practices and technologies. European fournal of Social Work, 21(6), 801-803. https://doi.org/10.1080/13691457.2018.1520475

López-Peláez, A., Marcuello-Servós, C., De-Mesa, J. C., \& Almaguer-Kalixto, P. (2020). The more you know, the less you fear: Reflexive social work practices in times of COVID19. International Social Work, 63(6), 746-752. https://doi.org/10.1177/0020872820959365

López-Peláez, A., Pérez-García, R., \& Massó, M. V. A.-T. (2017). E-social work: building a new field of specialization in social work? European fournal of Social Work(6), 1-20. https://doi.org/10.1080/13691457.2017.1399256

Mayer, R., \& Ouellet, F. (1991). Méthodologie de recherche pour les intervenants sociaux. Boucherville: Gaëtan Morin éditeur.

Mishna, F., Bogo, M., Root, J., \& Fantus, S. (2014). Here to Stay: Cyber Communication as a Complement in Social Work Practice. Families in Society, 95(3), 179-186. https:// doi.org/10.1606/1044-3894.2014.95.23

Pascoe, K. M. (2021). Considerations for integrating technology into social work practice: A content analysis of nine professional social work associations' Codes of Ethics. International Social Work. https://doi.org/10.1177/0020872820980833

Picornell-Lucas, A. (2020a). As crianças e os adolescentes confinados e invisíveis. In T. Moreira, A. Picornell-Lucas, M. A. Barbieri-Gonçalves, \& A. de Medeiros-Lima (Eds.), COVID-19, infância e adolescência: o novo mundo é um jardim ou uma cela? (pp. 11-18). Brasil: Editora Terra sem amos.

Picornell-Lucas, A. (2020b). ODS, COVID-19 e a proteção social de crianças e adolescentes: a experiência europea. In M. Conserva, E. Pereira, \& H. Menezes (Eds.), Desenvolvimento sustentável, territórios e políticas públicas (pp. 201-219). João Pessoa, Brasil: Editora UFPB.

Pimentel, I. F. (1999). A Assistência Social e familiar do Estado Novo nos anos 30 e 40. ., 34(151-152), 477-508. Retrieved from https://www.jstor.org/stable/41011371

Pink, S., Ferguson, H., \& Kelly, L. (2020). Child Protection Social Work in COVID-19. Anthropology in Action, 27(3), 27-30. https://doi.org/10.3167/aia.2020.270306

Reamer, F. G. (2017). Evolving ethical standards in the digital age. Australian Social Work, 70(2), 148-159. https://psycnet.apa.org/doi/10.1080/0312407X.2016.1146314

Reamer, F. G. (2018). Ethical Standards for Social Workers' Use of Technology: Emerging Consensus. Journal of Social Work Values \& Ethics, 15(2), 71-80. Retrieved from https:// jswve.org/download/15-2/articles15-2/71-Use-of-technology-JSWVE-15-2-2018-Fall 
.pdf

Rodrigues, E.-S.-C. (2012). Teoria da informação e adaptabilidade na modelagem de distribuição de espécies (Doctoral dissertation, EPUSP, São Paulo). Retrieved from https://www.teses.usp.br/teses/disponiveis/3/3141/tde-07052012-122345/publico/ Tese_Elisangela_Silva_da_Cunha_Rodrigues.pdf

Saitadze, I., \& Dvalishvili, D. (2021). Gaps between academia and practice: Perspectives on new graduates' readiness for social work practice in Georgia. International Social Work. https://doi.org/10.1177/00208728211026361

Singer, J., \& Brodzinsky, D. (2020). Virtual parent-child visitation in support of family reunification in the time of COVID-19. Developmental Child Welfare, 2(3), 153-171. https://doi.org/10.1177/2516103220960154

Sousa, L., Hespanha, P., Rodrigues, S., \& Grilo, P. (2007). Famílias Pobres: Desafios à Intervenção Social. Lisboa: Climepsi Editores.

Wagner, M., Spiker, D., Linn, M. I., \& Hernandez, F. (2003). Dimensions of Parental Engagement in Home Visiting Programs: Exploratory Study. Topics in Early Childhood Special Education, 23(4), 171-187. Retrieved from https://journals.sagepub.com/doi/pdf/ 10.1177/02711214030230040101

Wall, K. (2005). Famílias em Portugal: percursos, interacções, redes sociais. Lisboa: Imprensa de Ciências Sociais. 